\title{
BAZYLIANIE W POLSCE
}

Jubileuszowa roczntca 1600-lecia śmierci św.Bazylego ozywiła zainteresowanie jego osoba, nauka i dzlalalnościa, promieniująca na Koścí́ł Chrystusowy poprzez stulecia. Hówniez poprzez swoją dzlałalność monastyczną wpłynął w sposób zasadniczy na ukształtowanie się życia zakonnego Wschodu 1 Za$\operatorname{chodu}^{1}$. Po kilkuletnim pobycle wóród ówczesnych ascetów, anaohoretów 1 w pusteiniach zakonnych Wschodu stał sie z czasem, Jako aroybiskup Cozarei, znakomitym organizatorem cenobitalnych klasztorów w Kapadocji. Jednocześnie jego pisma ascetyczne, zwłaszcza "Reguły większe 1 mniejsze", stanowią pierwsza kodyfikacje nauki obyczajów 1 doskonałości zycia zakonnego. Obie reguky stanowia jak gdyby katechiza życia monastycznego. Przy opracowywaniu swej reguły św.Bazyli okazał slę zwolennikiem umiarkowanego ascetyzmu 1 wywarł trwały wpływ na dalszy rozwój wschodniego monastycyzmu. Nie dziwnego, ze uważany jest za patriarche mnichów Wschodu.

Reguły św.Bazylego, późnjejsi reformatorzy zakonni, przystosowywali często do potrzeb 1 warunków swogo czasu, lecz zawse pozostaly one "mlarodajng normę" zyola zakonnego. Tak waśnie na Ich podstawle, metropolita kijowski, Józef Welamin Rutski, przy współudziale św.Jozafata Kuncewioza, na pocz.

1 M.Szegda, Bazyli Wielki, Bazyllanie, EK II 135-138. K. BihlmeyerH. Tuechle, Historia Kościoła, tłum. ks.J.Klenowsk1, Warszaพล 1971 , I 363-364; N.Zernow, Wsohodnie ohrześcijaństwo, przełoży J.S.Loś, Warszawa 1967, 61-62. 
XVII w., zainicjowali w Wilnie reformę klasztorów Metropolii Kijorskiej, zjednoczonych ze Stolica Apostolską. Nowy zakon nawiazywał do ustawodawstwa biskupa Kapadocji $i$ nazywał sieb1e "Zakonem Bazyliańskim Rusinów /Ordo \$.Basili1 M. Muthenorum/, a od r. 1932, dla podkreślenia zasług św.Jozafata w odnowie bazyliańskiego zyoia zalionnego, przyjzł nazw̨: "Zakon Bazyliański śv.Jozafata". 0środkiem administracyjnym Zakonu by Ła Kuria Generalna w Rzymie z generalnym przełozonym - protoarchimandrytaz na czele.

Gdy w Jubileuszowym Roku Bazylianskim. ogarniany spojrzeniem całokształt wpływu wiolkiej postaci św.Bazylego poprzez wieki na życio zakonników, którzy nazywają go swoim ojcem, a siebie bazylianani, wypada równiez poświęcíc :troohę uwagi sytuacji tych bazylianów, którzy zyją 1 pracuja obecnie w Polsce. Organizacyjnyı ośrodkiem zespołu bazylianów $\$$ Polsce, jest obecnie klasztor w Warszawde przy-ul .Niodowej 16. Warszawslia siedziba bazylianska nawiazuje $i$ stanowi jakoby kontynuacje prowincji bazyliańskiej w Królestwie Polskim z XIX w. Po traktacio. bowiem w Tylży $/ 8$ VII $1807 /$, a nastapnie we niu /14 X 1809/w granicach powstałego Księstiva Warszawskiego, znalazło się pięć klasztorów bazyliańskich: w Chelmie, Białoj Podlaskiej, Warszawie, Zarnościu 1 Lublinie ${ }^{2}$. Z tych właśnie pięciu klasztorów utworzono nowa prowincję bazyliańska na kapitule w Chełmie 27 II 1810 roku, zwołanej przez Ferdynanda Dąbrowe Ciechanowskiego, administratora diecezj1 che1mskiej, który został wtedy wybrany pierwszym prowincjałem tych monasterów.

2 Ks.J.Kładoczny, Dzieje prowincji bazyliańskiej Wrólestwie Polsk1m, 1810-1864. "Sprawozdania Towarzystiva Naukowego we Lwowie", 16/1936/301-308. 
Tak uformowana prowincja bazyliańska w Królestiwie Polskim istniała ponad pięćdziesiąt lat aż do kasaty. Po powstaniu styczniowym, w którym wzięło udział zakonne 1 diecezjalne duchowienstwo rzymskokatoliokie, rzad rosyjski postanowi skasowab wlele klasztorów. Wprawdzie bazylianie nie brali udziału w powstaniu, ale rzad rosyjski podejrzewat ich o sympatyzowanie z powstancami, a także uważał, ze bazylianie nastawiaja ludność przeciw niemu usiłujłc skłoniś unitów, by przechodzili na obrzadek laciński. Totez oceniajác szkodliwość bazylianów dla panstwa rosyjskiego, postanowil skasowàc prowineje bazyliańska ${ }^{3}$. Pretekstem do kasaty była zbyt mała 11czba zakonników woszczególnych klasztorach bazyllańskich /rząd uważał, ze wedle wymagań prawa kanonicznego powinno $1 \mathrm{ch}$ byé co najmniej $8 \%$

otóz stan osobowy klasztorów polskiej prowincji bazyliańskiej w $1864 \mathrm{r}$. by 1 następujący: w Warszawie było 3 zakonników, w Chełmie - 11, w Lublinie - 1, w Białej - 8, w Zamościu - 2. Cała prowincja liczyła wlęc 25 bazylianów. liząd rosyjski jednak, stosując swotste restrykcje obliczeniowe, naliczył we Chełnle tylko 5 zakonników, w Białej zaś - tylko 2 W najblizszaz noc po ogłoszentu ukazu rządu rosyjskiego - kasacie prowincji bazyliańskiej 28 listopada 1864 r., zlikwidowano klasztory bazyliańskie w Chełıie, Białej Podlaskiej, Lublinie i Zanościu. Zakonników zaś, zwłaszcza z. Chełma i Bialej, przeniesiono do klasztoru w Warsawie. Jednak przy bazyliańskich cerkwiach klasztornych pozostawiono nadal po jednyın zakonniku /w Białej nawet 2/, aby zachować ciagłość od-

3 Ks.J.Kładoczny, Ostatnie chwile prowinoji bazyliańskiej w Królestwie Polskiem, PT 15/1934/93-103. 
prawlania nabożeństw. Majątki zaś po skasowanych klasztorach bazyliańskich miały przejść w posiadanie rządu. Także 1 klasztorowi warszawskiemu odebrano caky jego majątek, natomiast rząd miał wypłacać na utrzymanie jego zakonników stała pensje w kwocie 2.500 rubli rocznie. Skonfiskowany majątek nieruchomy prowincji miano obrócić na utrzymanie klasztoru warszawskiego oraz na polepszenie dotacji kleru świeckiego. Ci zaś z zakonników, którzy jako wikariusze pozostaliby przy cerkwiach skasowanych klasztorów, mieli pobierać 110 rubli rocznej pensji.

Zakonnikom zlikwidowanych klasztorów bazyliańskich pozostawiono do wyboru albo przenieść sie do klasztoru warszawskiego, i tu dalej kontynuować zycie zakonne, albo do któregokolwiek klasztoru bazyliańskiego, znajdującego się poza granicari ilosji. Tym, którzy zechcieliby wyjechać, obiecano na droge pieniądze, oraz zapewniono utrzymanie od poselstwa rosyjskiego w wysokosici 130 rubli rocznie.

Prowincja bazyliańska w czasie kasaty 1864 r. liczyła 25 zakonników, z których kilku wyjechało za granicę, kilku sekularyzowało się, 14 zaś osiadło na stałe w Warszawie. Klasztor warszawski poddano całkowicie pod władze biskupa chełnskiego, a zakonnikom zabroniono kontaktować się z prowincjałami lub innymi władzani zakonu. Biskup chełmski przez swego specjalnego wizytatora, miał troszczyé się o to, ażeby w klasztorze panowal porządek, zgodnie z prawami kościelnymi. Zakonnikom klasztoru warszawskiego zakazano odbywać kapituł klasztornych 1 innych zebrań. Klasztor warszawski z zakonnikami poddano szczególnemu nadzorowi. władzy świeckiej, a poruszante się 1 ch poza klasztorem inwigilacji rosyjskiej policji.

Jednak kasata prow1noji bazylianów w $1864 \mathrm{r}$. oraz wszel- 
k1e ograniczenla dotyczace ich ostatniego klasztoru warszawie, nie zadowolity rzadu rosyjskiego. Klasztor ten istniaz jeszcze tylko 8 lat 1 został skasowany ukazem cara Aleksandra II 1872 r., cerklew zaś zamieniona wyłacznie na parapialną, a 1875 r. na cerkiew prawosławna poświęconą 25 stycznia $1876 \mathrm{r}$. na nowo przez prawosławnego arcybiskupa Leoncju8za. Niektórzy z bazyllanów przyjęl1 wtedy obrządek łacínski, Inni przenié́li się do prowincji halickiej lub objęli unickie probostwa, jeszcze inni, ku którym specjalnie skierowana była nlechęc rządu.- posady prywatne.

Czterdziésci lat później wybuchła I wojna światowa, 1915 r. zajeta została Farszava przez wojska niemieckie. Wtedy pobazyliańska cerkiew, przy ulicy Miodowej 16, zamieniono na koścí́ł katolick1, a przy nim osadzono ostatniego żyJącego jeszcze bazylianłna, Jedynego, który pozostał przy życlu z całej prowincji, o.Grzegorza Nieckiewicza/właściwie Gabriela Furmana, który w czasie kasaty w 1864 r., mieszkał w klasztorze w Chełmie/: 0.Furman po 1915 r. ży jeszcze w klasztorze przy kościele bazylianiskim cztery lata 1 zmarł jako 80-letni starzec dnia 7 września 1919 roku. Po jego śnierci rząd polski, dom 1 kośclół pobazyliański przy ulicy Miodowej, oddal w uzywanie lwowskiemu arcybiskupowi obrzadku ormiańskiego, Józefowi Teodor owiczowi. Msze św. wościele odprawiały się jednak w obrządku łacińskim. Arcybiskup warszawsk1, kard. Aleksander Kakowski, w 1929 r. przekazał ów dom 1 kościół oo.bazylianom z prowincji Najśw. Zbawiciela ze Lwowa, na greckokatolickle nabożeństwa 1 dla obsługi duszpasterskiej grekokatolików, a w 1937 r. utworzył przy cerkwi greckokatolicka parafie. Przy klasztorze 1 cerkwi mieszkało zazwyczaj trzech ojców 1 dwu braci zakonnyah. 
Chwile grozy przezyli bazylianie w czasie II wojny éwiatowej, szczególnie podczas powstania warszawskiego. Naoczny świadek brat zakonny Ignacy oleśków relacjonuje: "Piwnice pod klasztorem były przepełnione chowającymi sie mieszkaricami Warszawy. Straszna zaducha, brak powietrza wiwnicach, panika przed Niemcam1, którzy rozstrzeliwali ludność na Wo11. 12 sierpnia $1944 \mathrm{r}$. spadła bomba niemiecka na prawa część domu 1 zniszczyła trzy piętra do parteru. Zginaz wtedy brat zakonny Beniamin Kłaczyŕski, którego bomba rozntosła na proch 1 śladu nie zostało po nim. Cięźko byz ranny równiéz bazylianin o.Klemens Kiernicki 1 od ran tegoz dnia zmar 1 . Pochowano go w ogrodzie bazyliańskim. W tydzień pózntej zapalająca bomba niemiecka spadła na tę samaz zniszczoną część domu. Podpa111 sie wtedy wegiel w pirnicy 1 spłoną dach nad cerkwia oraz na lewej części domu. 28 sierpnia Niomcy dali rozkaz ewakuacji ludności do Pruszkowa. Dwóch ojców: Orest Jaworski 1 Jozafat Dacyszyn, 1 dwóch braci zakonnych: Ignacy Oleśków i Józep Grodzki, szli pieszo az do Pruszkowa, do obozu. Ojcowie 1 bracia już następnego dnia znaleźli tymczasoły przytu-. łek u Sióstr Samarytanek w Pruszkơie

Dzielem Opatrzności było to, ze o. Paweł Puszkarski, przełożony klasztoru bazylianów od 1929 r., zakonnik niezwykłej świątobliwości 1 zacności, znany spowiednik sióstr zakonnych, na tydzleń przed powstaniem wyjechal do 0twocka, by prowadzió rekolekcje dla sióstr, 1 tam azczęśliwio przetrwał powstanie. Powrócił on do Warszawy zaraz po zakończeniu wojny, wiosna 1945 r., 1 tu wynająl mieszkanie przy ul.Górnośląskiej 16, gdzie zarazem urządził kaplice. Jednocześnie przy pomocy

4 Ze wspomnień utrwalonych na taśmie magnetofonowej warszawie, 21 I 1976. 
brata Ignacego 0lé́kowa, który powrócił do Warszany 1ätem, o.Puszkarski zabrał sie do odgruzowywania 1 odbudowy spalonego 1 na wpół zruinowanego domu bazyliańskiego przy ul.Miodowej 16. Subsydia na to częściowo otrzymywał od Urzędu Odbudowy Stolicy. Także ks. prymas kardynał August HJond wzczególny sposób udzielał swngo poparcla 1 pomocy o.Puszkarskiemu odbudowywaniu domu, a wikariusz generalny, k\&.bp Wacsaw Majewski, zyjąc w wielkiej przyjaźni z o.Pusz-. karskim, ma jego prośbe ułatwial zbieranie kwesty przez siostry zakonne na dźwignięole z ruin bazyliańskiego domu. Koszty odbudowy domu siggały kilku milionów złotych. Dzięki umiejetnyu 1 energioznym zabiegom o.Puszkarskiego 1 zebranym jałmużnom, już w jesieni 1948 r. 3 ojców 13 braci przeniosło się z ulicy Górnó́ląskiej 1 zamieszkało w częściomo odremontowanym domu bazyliańskim przy ulicy Miodowej. I 1949 roku odremontorano cerkteiv, której rekongekracji we wrześniu dokonał ks.prymas Stefan Wyszyński. Bazylianie korzystajao w niej z birytualizmu, odprawrali nabożeństwa przewaznie " obrządku łacińskim, a na Wielkanoc 1957 r., z błogosławieństwem ks.Prymasa, celebrowano w cerkw1 śplewanq Mszq ów. w obrządku greckokatolickim. Od tej pory w kaźda niedziele odprawiano liturgle wschodnia.

W 1957 r., z bazylianów, zamieszkałych w Polsce, została utworzona delegatura z ó́rodkiem w klasztorze warszawskim, a jego przełożony - thumen jest zarazem delegatem protoarchimandryty, $z$ prawami prowincjala nad bazyllanami w Polsce. W domu warszawskim umieszozono jednocześnie nowicjat 1 dom klerykór bazyllańskich, którzy przygotowując 810 do kapłaństwa, uczęszczaja na wykłady do archidiecezjalnego 
seminarium duchownego lub na wyzaze uozelnie.

W Jubileuszowym 1979 Roku Bazyliańskim stan delegatury bazylianów w Polsce był następujacy: W a $r$ s a w $i$ e było 2 ojców, 3 braci zakonnych, 4 kleryków 12 nowicjuszy - razem 11 osób; w W g o r z e 1 e /diecezja olsztyńska/ w domu bazyliańskim, zakupionym 1977 r., znajdowa?o sie 4 ojców / w tym - 1 chory/, którzy obṣługiwali 7 greckokatolict:1ch placówek duszpasterskich: w Wegorzewie, Miłkach, Baniach Mazurskich, Kruklankach, Bajorach Wielkich, Wydminach 1 Chrzanowie; w $\mathrm{S}$ a $\mathrm{r}$ g a $r$ d $z$ e Szczecińskimmleszkało 2 ojców, którzy obsługiwali 4 greckokatolickie placówki duszpasterskie: w Stargardzie, Ińsku, Szczecinie i Swidwinie; w P r z e m y ś 1 u juz w 961 r. 1 bazylianin zaczął prowadzió całe greckokatolickie duszpasterstwo w mieścle /2 w latach 1964-1967/. W 1966 r. zakuplono dom bazyliański przy ul.Krajowej Rady Narodowej 10.. Z poczatkiem 1968 r. duszpasterstwo w Przemyélu przejal ks. mitrat Bazyl1 Henryk z ramienia greckokatolickiej kapituly przemyskiej. Od tej pory w rezydencj 1 bazyliańskiej w Przenysilu mieszka 1 ofciec, który wedle potrzeby pomaga w duszpasterstwie w Przemyślu 1 lirebennem oraz prowadzi greckokatolickie duszpasterstwo w Jarosławiu. Wreszcie 1 ojclec mieszka w T $\mathbf{r}$ o b 1 a $t \circ$ w 1 e pod Szczecinem obsługujac tam greckokatolicka placówkę duszpasterska oraz w Kołobrzegu.

Obecnle więc w Polsce jest 19 bazyl1anów w tym 10 kapłanów, 3 braci zakonnych 16 kleryków. Mieszkają oni w plęciu domach zakonnych, czy rezydencjach 1 wspomagaja lub kioruja 17 greckokatolickimi placówkami duszpasterskimi. Jednocześnie prowadza dzialalność misyjno-apostolską, głosząo, zwłaszcza wielkim Poście, kilkanaście seril parafialnych rekolekcji. 
Swoja formacje duchowa oo.bazylianie delegatury w Polsce opieraja na "Konstytucjach", wydanych drukiem w $1977 \mathrm{r}$. dla całego zakonu bazyllańskiego św.Jozafata ${ }^{5}$. Konstytucjo. 8a opracowane zgodnie $z$ instrukcja Soboru Watykánskiego II, wydana dla odnowienia 1 unowocześnienia katolickich zgromadseń zakonnych. "Konstytucje Zakonu áw.Bazylego W." składaJą sie z trzech części: "Ustaw - Reguły - Regulamin". "Ustaw" zawiera"Naukę Kó́cioła o chrześcijańskiej świętości"/s.152乞/ oraz "Asceze sw.Bazylego 1 jego ustaw" /8.24-63/. W tej drugiej ozęśol są cytowane słowa św.Bazylego o zyciu zakonnym. Interesujące byłoby porównanie paralelnych mlejsc nauk1 Kośloła z zasadami podanymi przez patriarchę zycia monastycznego św.Bazylego. Dla przykładu warto przytoczyd́ słowa - oelu zyoia zakonnego. Kościół naucza: "wszyscy chrześcijanie są powołani 1 zobowiazani do świętości 1 doskonałości własnego stanu poprzez miłość Boga 1 bliźnlegon świętość zaś w szczególny sposób przejawia sie w praktykowaniu rad ewangelioznych" - ubóstwa, czystości i posłuszeństwa. Analogiczne zasady znajdujemy we fragmentach monastycznych pism áw.Bazylego zawartych $w$ obecnym bazyliańskim "Ustawie", np. - "oelu - f́więtości życia" naucza Bazyli: "za bożą łaską tutaj zebraliśmy się w imię Pana naszego Jezusa Chrystusa. I mamy wszyscy ten sam cel: świętośó zycia". W dalszej części "Ustawu" bazylianskiego cytowane squ urywki pism św.Bazylego, tyczące miłości Boga 1 bliźniego, czy rad ewangelicznych: ubóstwa, czystó́ci 1 posłuszeństwa.

Nawet te ogólnikowe zestawienia nauki Kościoła katolio-

5 Konsty tucjji Czynu áw. Wasyłija Wełykoho. Ustaw - Prawyła - Prawylnyk, Rym-Toronto 1977, 324. 
kiego o życiu zakonnym w obecnym czasie, z zasadami, zaczerpniętymi z pism św.Bazylego, wskazują na niegasnącą aktualność oraz wpływ jego geniuszu w przeciagu długich stulec1, a nawet tysiącleci na źcie zakonne wościele Chrystusowym.

$$
\text { O.Borys Jan Bałyk OSBM }
$$

\section{ENCYKLIKI I LISTY \\ PAPIESKIE O OJCACII KOSCIOLA I ICH NAUCE}

Wydawcy dzieł 0jców Kościoła z poprzednich wieków /XVI-XVIII w./ mieli dobry zwyczaj poprzedzania tekstów śriadectwami róznych autorytetów, przede wszystkim patrystycznych, o loh zyciu $i$ nauce. W znacznie skromniejszej mierze lub wcale tego nie czynia wydawcy dzisiejsi: A szkoda, bo jest rzecza niezmiernie interesujaca poznanie tego, co - Ojcach myśleli ludzio im współcześni i uczeni następnych wieków. Migne, wydawca monumentalnej serii Patrologia Graeca i Patrologia Latina, przedrukował te dawne opinie, zwa szcza przy ojcach opracowanych przez niedoścignionych Maurynów.

Na przestrzeni ostatnich mniej więcej stu lat utarł sie inny pozyteczny zwyczaj, a mianowicie, zabieranta głosu przez papiezy w formie encyklik, listów albo przenówień z okazji roczntc 0jców Koścłoła lub jakłegó́ wiekszej wagi wydarzenia z historil Kościoła staroży tnego, np. soboru. Dokumenty te nie saz tylko okolioznosiclowym hołdem dla wielkioh postaci minionych wieków, lecz miarodajna wskazówka, jak dziś patrza na ojoów najwyższe czynniki kościelne, jak oceniaja 1 ch 